\title{
SOME DURABILITY ASPECTS OF AMBIENT CURED BOTTOM ASH GEOPOLYMER CONCRETE
}

\author{
R.SARAVANAKUMAR ${ }^{1}$, V.REVATHI ${ }^{2}$
}

\begin{abstract}
The present study examines some durability aspects of ambient cured bottom ash geopolymer concrete (BA GPC) due to accelerated corrosion, sorptivity, and water absorption. The bottom ash geopolymer concrete was prepared with sodium based alkaline activators under ambient curing temperatures. The sodium hydroxide used concentration was $8 \mathrm{M}$. The performance of BA GPC was compared with conventional concrete. The test results indicate that BA GPC developes a strong passive layer against chloride ion diffusion and provides better protection against corrosion. Both the initial and final rates of water absorption of BA GPC were about two times less than those of conventional concrete. The BA GPC significantly enhanced performance over equivalent grade conventional concrete $(\mathrm{CC})$.
\end{abstract}

Keywords: bottom ash, alkaline activators, ambient curing, accelerated corrosion, sorptivity, water absorption

\section{INTRODUCTION}

Concrete usage has spiked in the past few decades due to quickly-growing construction activity across the world. Cement is the main ingredient of the concrete matrix which gives binding properties, which is inevitable in concrete. But, mass production of cement releases huge amounts of $\mathrm{CO}_{2}$ into the atmosphere which leads to an increase in environmental degradation ((Malhotra (2002); Mohammed Ba-Shammakh et al. (2008); Emad Benhalal et al. (2012)). In order to reduce the usage of cement and carbon emissions, cement less concrete known as geopolymer has emerged in the past few decades ((Davidovits 1970 \& 1991; Rangan (2005, 2006 \& 2008)).

\footnotetext{
${ }^{1}$ Assistant Professor (Sr.G), Department of Civil Engineering, KPR Institute of Engineering and Technology, Coimbatore, Tamilnadu, India, e-mail; saravanakumartg@gmail.com.

${ }^{2}$ Professor and head, Department of Civil Engineering, K.S.R.College of Engineering, Tiruchengode, Tamilnadu, India, e-mail; revthiru2002@yahoo.com.
} 
Subsequently, abundant studies were carried out on geopolymer concrete using fly ash, which is enriched with silica and alumina. Silica and aluminium react with alkaline liquids to form a geopolymer binder (Fernandez-Jimenez and Palomo, 2003; Duxon et al, 2005; Fernandez-Jimenez et al 2006). Apart from fly ash, many other materials like GGBS, rice husk ash, metakaolin, etc. are evaluated in promoting geopolymers. Still, very little research is available on the use of bottom ash in geopolymers. Bottom ash is a dark gray, granular, porous material which is collected during the process of burning coal in a furnace. Several studies were done on the use of bottom ash as a cement replacement material and as a fine aggregate in cement concrete ((Milagre Martins et al. (2010); Diana Bajarea, et al. (2013); Kim and Lee (2011); Malkit Singh and Rafat Siddique (2014); Aggarwal et al.(2007); Ghafoori and Bucholic (1997)). Additionally, bottom ash use has been attempted in geopolymers after making its coarser particles into finer ones ((Chindaprasirt et al. (2009); Apha Sathansaowaphak et al. (2009); Ilker and Mehmet (2011); Caicharn Chotetanorm et al. (2013); Revathi et al.2014; Logeshkumar and Revathi. (2016)). In fact, fine ground bottom ash geopolymer concrete achieved remarkably higher strength under heat curing when a higher sodium hydroxide concentration was used ((Si-Hwan Kim et al, (2012); Vanchai Sata et al (2012); Caicharn Chotetanorm et al. 2013)). However, Revathi et al. (2014) found that bottom ash geopolymer mortar attained appreciably higher compressive strength under ambient curing. Also, a study on bottom ash blended with fly ash was reported by Tianyu Xie and Togay Ozbakkaloglu (2015 and 2015a) as a method of making geopolymer concrete.

Caicharn Chotetanorm et al. (2013) found that fine bottom ash geopolymer mortar attained a low sorptivity rate and voids are very little to take up the water. Tianyu Xie and Togay Ozbakkaloglu (2015) stated that coarse bottom ash blended with fly ash reached lower geopolymerisation than fly ash based geopolymer concrete. Due to its larger particle size, this blend reached maximum water absorption. The water absorption rate of low calcium fly ash geopolymers was very low in all aspects. Geopolymer concrete has less $\mathrm{CaO}$ in comparison with conventional concrete. Therefore, naturally, geopolymer concrete has the tendency to perform well against durability aspects, and hence delaying the accelerated corrosion rate ((Bastidas et al (2008); Monita Olivia and Nikraz (2011 and 2012); Reddy et al. (2011)).

It can be deduced from the past studies that no sufficient work has been carried out on the durability aspects of bottom ash geopolymer concrete. Particularly, the sorptivity and acceleration corrosion rates under ambient curing temperatures have not been examined. Accordingly, the present study has taken up to assess the performance of bottom ash geopolymer concrete based on acceleration corrosion, sorptivity and water absorption. 


\section{MATERIALS AND METHODOLOGY}

\subsection{MATERIALS}

\subsubsection{ORDINARY PORTLAND CEMENT (OPC)}

Ordinary Portland cement (OPC) (53 grade) was used as a binder for casting conventional concrete. Cement used was conforming to IS 12269-2013 and the specific gravity of the cement was found to be 3.15, according to IS 4031 (Part 11): 1988.

\subsubsection{BOTTOM ASH}

In this study, bottom ash which was collected from the Mettur Thermal power plant in a wet condition was used as a source material in the geopolymer concrete matrix. It was properly dried and grinded as much as possible to obtain particles a size lower than $45 \%$. The specific gravity of the bottom ash was found to be 2.17. The chemical composition in wt \% of the bottom ash was: $51.50 \% \mathrm{SiO}_{2}, 32.58 \% \mathrm{Al}_{2} \mathrm{O}_{3}, 5.92 \% \mathrm{Fe}_{2} \mathrm{O}_{3}, 0.21 \% \mathrm{MgO}, 5.19 \% \mathrm{SO}_{3}, 0.50 \% \mathrm{CaO}, 1.35 \% \mathrm{Na}_{2} \mathrm{O}$, $0.58 \% \mathrm{~K}_{2} \mathrm{O}$ and $1.50 \%$ LOI.

\subsubsection{ALKALINE ACTIVATORS}

The chemical solution responsible for the polymerisation process is known as an alkaline activator. A combination of sodium silicate and sodium hydroxide as alkaline activators was used in this experiment. The sodium silicate solution and sodium hydroxide flakes were procured from a local supplier in bulk. The sodium hydroxide flakes were dissolved in water to make a solution based on the required molarity (Rajamane and Jeyalakshmi 2015).

\subsubsection{AGGREGATES}

River sand conforming to zone III classification was used as the filler material for the present study and it was tested as per IS 383-1987. The specific gravity of the river sand was 2.65. Coarse aggregates $12 \mathrm{~mm}$ and $6 \mathrm{~mm}$ in size were used. The specific gravity of the coarse aggregates was 2.8 


\subsection{PROPORTIONS, MIXING, AND CURING}

Mix proportions were calculated for both conventional concrete and bottom ash geopolymer concrete. The geopolymer concrete mix design was followed according to the guide lines proposed by Rangan (2008). Conventional control concrete (CC) mix proportions were attained per IS 10262 : 2009. The alkaline ratio of sodium silicate to sodium hydroxide was used as 2 . The sodium hydroxide concentration as $8 \mathrm{M}$ and molar ratio of $\mathrm{Si}_{2} \mathrm{O}$ to $\mathrm{Na}_{2} \mathrm{O}$ as 1 was used in this work. The amount of alkaline solution was taken as 0.5 times the weight of source material. The mix design of the concrete was made at a density of $2400 \mathrm{~kg} / \mathrm{m}^{3}$. In both the BA GPC and cement concrete, CC mix proportions were made for a grade of $40 \mathrm{MPa}$. Control concrete with cement as binder was made for comparison purposes. The complete mix proportions are displayed in Table 1. Mixing of all ingredients was done in a pan mixer in order to attain a homogeneous mix, and afterwards it was cast into moulds. The casted specimens were compacted in a table vibrator and then the cube surface was perfectly finished. The specimens were demoulded after 24 hours and allowed to cure until testing time. Water curing was used for conventional concrete and ambient curing was used for the geopolymer concrete specimens.

Table 1. Mix proportions of BAGPC and CC

\begin{tabular}{|c|c|c|}
\hline Materials & CC & BAGPC \\
\hline Cement $\left(\mathrm{kg} / \mathrm{m}^{3}\right)$ & 394 & - \\
\hline Bottom ash $\left(\mathrm{kg} / \mathrm{m}^{3}\right)$ & - & 400 \\
\hline Sodium hydroxide $\left(\mathrm{kg} / \mathrm{m}^{3}\right)$ & - & 66.7 \\
\hline Sodium silicate $\left(\mathrm{kg} / \mathrm{m}^{3}\right)$ & - & 133.3 \\
\hline Fine aggregate $\left(\mathrm{kg} / \mathrm{m}^{3}\right)$ & 629.6 & 540 \\
\hline Coarse aggregate $\left(\mathrm{kg} / \mathrm{m}^{3}\right)$ & 1216.1 & 1260 \\
\hline Water $\left(\mathrm{kg} / \mathrm{m}^{3}\right)$ & 157.6 & - \\
\hline Super plasticizer $\left(\mathrm{kg} / \mathrm{m}^{3}\right)$ & 7.88 & 8 \\
\hline
\end{tabular}

\subsection{COMPRESSIVE STRENGTH}

The compressive strength of BA GPC and CC was determined using $150 \mathrm{~mm}$ cubes as per IS 516 1959 (reaffirmed 2004). The specimens were tested at 3, 7, and 28 days of curing using a hydraulic digital compression testing machine with a capacity of $2000 \mathrm{kN}$. A total of 9 specimens of BA GPC and another 9 specimens of control concrete were made to determine the compressive strengths of both the BA GPC and control concrete. The test results were compiled from the average of three specimens. 


\subsection{ACCELERATED CORROSION TEST}

An accelerated corrosion test was performed according to the Florida test method (FM 5-522 2000). In order to determine the accelerated corrosion of BA GPC, a cylindrical specimen of 100 $\mathrm{mm}$ dia and $200 \mathrm{~mm}$ height was used. In the cylindrical specimen, a steel rod $16 \mathrm{~mm}$ in diameter was embedded at the centre into a depth of $30 \mathrm{~mm}$ from the bottom of the surface. The 28 day-cured specimens were placed in a container filled with $3.5 \% \mathrm{NaCl}$ solution, reaching two-thirds of the height of the cylinder. The steel rebar acted as an anode. One end of the insulated wire was attached to the exposed steel rebar placed in the container, and its other end was connected to a DC power supply. An external stainless steel plate kept in the container acted as a cathode. A constant potential of $12 \mathrm{~V}$ was applied to the specimens. This arrangement would penetrate the chlorine ion into the concrete. The current passing through the specimen was observed at regular intervals. Sudden change in current indicates corrosion initiation. The measurements were recorded continuously until failure of the concrete specimen. Thus, test time was extended until the specimen had undergone failure. After observations made during testing, a graph was plotted between current passed and time, which clearly shows how much time is required for effecting corrosion. A total of 6 specimens were tested to understand the behaviour of BA GPC and CC in corrosion conditions. The test results were obtained for an average of three specimens.

\subsection{SORPTIVITY TEST}

The rate of sorptivity of the test specimens was obtained in accordance with ASTM C 1585 - 2013. Concrete discs $100 \times 50 \mathrm{~mm}$ in size cut from the parent sample were used for determining the rate of sorptivity. The test was conducted on 28-day-cured specimens. The side surface of the specimen was sealed with waterproof sealant to permit the water from penetrating through the bottom surface via capillary action. The top surface, which was not exposed to water, was covered with a plastic sheet.

The initial mass of the sealed specimen was measured and recorded. The supporting device was placed at the bottom of the container. The container was filled with water in such a way that the water level was $3 \mathrm{~mm}$ above the top of the support device upto the duration of the tests. The 
specimen was placed on the supporting device and the time of first contact with water was immediately recorded. The mass of the specimen was recorded at the intervals mentioned in the code. The amount of absorbed water was calculated using the following equation 2.1.

$$
\mathrm{I}=\Delta \mathrm{m} / \mathrm{a} \times \mathrm{d}
$$

Where

$$
\begin{array}{ll}
\text { I } & \text { - absorption in } \mathrm{mm} \\
\Delta \mathrm{m} & \text { - the change in mass of the specimen in gm at the time t } \\
\mathrm{a} & \text { - the exposed area of the specimen in } \mathrm{mm}^{2} \\
\mathrm{~d} & \text { - the density of water in } \mathrm{gm} / \mathrm{mm}^{3} .
\end{array}
$$

\subsection{WATER ABSORPTION TEST}

In this study, water absorption was determined as per ASTM C 642-13 standards. For determining the water absorption of BA GPC, specimens $100 \times 100 \times 100 \mathrm{~mm}$ in size were used. The 7- and 28day-cured specimens were dried in an oven at $100^{\circ} \mathrm{C}$ for 24 hours. The oven-dried specimens were allowed to air cool at room temperature and their mass was then determined. The initial mass of each specimen was noted as (A). The specimens were then immersed in water for a period of 24 hours to record saturated mass. Then final mass of the specimen was then noted (B). Water absorption was calculated from equation 2.2 given below.

$$
\text { Water absorption } \%=[(\mathrm{B}-\mathrm{A}) / \mathrm{A}] \times 100
$$

A total of 12 specimens were tested to examine the water absorption of BA GPC and CC. The test results were obtained from an average of six specimens.

\section{RESULTS AND DISCUSSION}

\subsection{COMPRESSIVE STRENGTH}

The compressive strengths of BA GPC and CC are presented in Table 2. The strength results indicate that BA GPC achieved notable improvement when compared to conventional CC. It is 
clear that BA GPC exhibited $18.8 \%, 11.1 \%$, and $5.7 \%$ higher compressive strengths than the control concrete at the ages of 3, 7, and 28 days, respectively. Fine bottom ash contributes to an increase in the geopolymerisation process, thereby resulting in higher compressive strength (Vanchai Sata et al, 2012). High strength was also attributed to highly reactive silica present in bottom ash (FernandezJimenez and Palomo, 2003). Another important parameter in the geopolymer reaction is the amount of alumina present in the starting material. A minimum of $20 \%$ of reactive alumina is required to achieve better strength development (Fernandez-Jimenez et al (2006). In the present study, bottom ash contains $32.58 \%$ alumina, which greatly contributes to strength enhancement. Performance of aluminiosilicate activation is favorable when sodium hydroxide concentration is $8 \mathrm{M}$. At higher alkalinity, primarily sodium hydroxide simulates the ionic strength in the binder activating the solution and dissolves the silicon and aluminum present in the source material (Duxon et al, 2005). It can also be emphasized here that BA GPC achieved strength under ambient curing, while heat curing is recommended for activation in geopolymer concrete ( Rangan and Wallah, 2008). In fact, this finding gives geopolymer concrete an avenue for its acceptance to produce similar to conventional cement concrete onsite.

Table 2 Test Results for Compressive Strength

\begin{tabular}{|c|c|c|c|}
\hline \multirow{2}{*}{ Sl.No } & \multirow{2}{*}{ Age (days) } & \multicolumn{2}{|c|}{ Compressive strength (N/mm2) } \\
\cline { 3 - 4 } & & CC & BA GPC \\
\hline 1. & 3 & 21.7 & 24.1 \\
\hline 2. & 7 & 28.7 & 34.1 \\
\hline 3. & 28 & 47.6 & 50.3 \\
\hline
\end{tabular}

\subsection{ACCELERATED CORROSION}

Corrosion of steel reinforcements has a strong impact on the life of concrete structures. In fact, steel which is embedded in an alkaline environment develops a thin protective coating on its surface which provides adequate protection against corrosion. However, over time, this protective layer may disintegrate due to the ingress of chloride ions resulting in a decrease of alkalinity, leading to corrosion. Therefore, an accelerated corrosion test was carried out in the present study to understand the behaviour of BA GPC against corrosion. In the accelerated corrosion test, the current passed through the specimens was observed over a specified duration. Typically, two observations were made in the corrosion study including corrosion initiation time and time at which first crack was noticed. Corrosion initiation is noted by visual observation when rust appears on the top surface of 
the specimen. When an abrupt increase in the current reading is noticed, it indicates the time of crack. Current variation over time is illustrated in Fig. 1. It can be seen that the profile is characterised with an initial decrease in current manifesting the formation of an iron oxide layer which represents the slow process of corrosion. Further, the current rate becomes constant until the first crack appears on the specimens. During this stage, the corrosion initiation time was observed at $312 \mathrm{hrs}$ for CC and $552 \mathrm{hrs}$ for BA GPC by visual observation alone. The corrosion initiation time of BA GPC was 1.76 times delayed in comparison with CC. After reaching constant current values, current shot up due to the rapid invasion of chloride ions into the specimen indicating the time of first crack. After the first crack, the current reading progressed slowly until the specimens ruptured. The time of crack was noted at $552 \mathrm{hrs}$ for CC, while for BA GPC it was $742 \mathrm{hrs}$. This result reveals that BA GPC exhibited $25 \%$ higher longevity than conventional concrete. The onset of corrosion is visualized by the appearance of brown patches on the surface of the specimens when their reinforcement starts corroding. The appearance of brown patches was severe in CC specimens, while it was relatively less in BA GPC. This tendency confirms that BA GPC creates a strong passive layer against chloride ion diffusion in the cell and provides better protection against corrosion. Similar findings were reported by Monita Olivia and Nikraz, 2011; Xie and Ozbakkalogu, 2015 in their studies on geopolymer concrete made with fly ash. Furthermore, pH value is a key factor influencing the durability of concrete. Steel reinforcement in concrete can be protected when the $\mathrm{pH}$ value is maintained in the range of 12.5 to 13.5 (McPolin, 2007). When $\mathrm{pH}$ value falls below 11, it causes a loss of the passive oxide layer in the rebar. Also, the ingress of chloride salts into the concrete gradually reduces the $\mathrm{pH}$ value and rapidly increases corrosion reactions. Yodmunee and Yodsujai (2006) reported that GPC has a very low rate of corrosion, as the matrix has a high $\mathrm{pH}$ value after the reaction because of its high alkaline content. Bastidas et al (2008) stated that activated fly ash mortars passivate steel reinforcements similarly to conventional cement concrete. Thus, the longer corrosion resistivity of BA GPC indicates that it has maintained a high $\mathrm{pH}$ value and can passivate steel reinforcements effectively. Moreover, the passive state stability depends strongly on the compounds used to activate the start material (Monita Olivia and Hamid Nikraz, 2012). In the present study, the higher the amount of both bottom ash and alkaline solution in GPC, the more increased the cathodic reaction and decreased corrosion activity. 


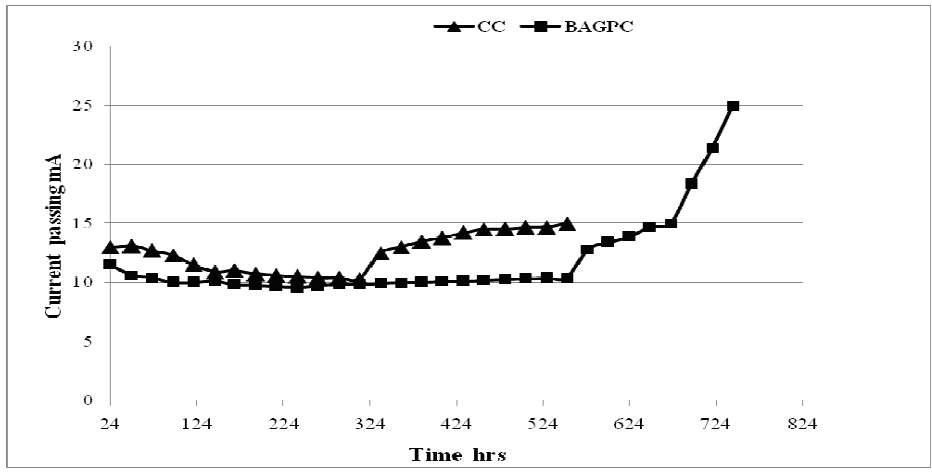

Fig.1 The Relationship Between Current Passed and Duration of Time

\subsection{SORPTIVITY TEST}

Damage to concrete structures occurs due to the migration of aggressive substances from the adjacent areas into the concrete. In fact, many construction materials are porous in nature and are affected by the ingress of moisture. The presence of moisture in the structure becomes the source of several durability issues; Hall (1977 and 1989) suggested studying the uni-directional flow of water through a given material. It is also said that concrete with low absorption properties is of good quality. The quality of concrete improves with curing age and depends on the source and type of material used. Ho and Chirgwn (1996) state that the use of admixtures as a replacement for cement concrete greatly improves the quality of the concrete. Consequentially, it is also essential to assess the absorption properties of BA GPC.

As per the guidelines of ASTM C 1585 -2013, observations were made upto 8 days (i.e. up to $11520 \mathrm{~min}$ ) and the test results of the sorptivity of the concrete are presented in Table 3 . The initial absorption of CC and BA GPC for the first $6 \mathrm{hrs}$ was found to be 0.921 and $0.455 \mathrm{~mm} / \sqrt{\mathrm{min}}$, respectively. The final absorption measured from day 1 to day 7 was 0.206 and $0.099 \mathrm{~mm} / \sqrt{\mathrm{min}}$ for $\mathrm{CC}$ and BA GPC. It can be stated that the initial and final rates of water absorption of BA GPC were nearly two times less than those of CC. BA GPC exhibited a lower absorption of water (due to the capillary rise action of water) than the control concrete made with cement, $\mathrm{CC}$. The low sorptivity value of BA GPC endorses the good quality of the concrete. Also, the higher compresive strength of BA GPC imparted a lower absorption of water. The reasonably lower sorptivity 
indicates that BA GPC was much denser, more homogeneous, and less permeable compared to conventional concrete. This is mainly attributed to the filler effect of bottom ash microparticles and also to the geopolymerisation reaction between bottom ash and alkaline activators. This physical and chemical effect causes a reduction of pore sizes in the BA GPC thereby preventing the aggressive liquid from ingressing into the pore system. This observation confirms the findings of Caicharn Chotetanorm et al, (2013) on the study of BA GP mortar. The increased sorptivity of CC may be due to the presence of calcium hydroxide. In fact, the calcium hydroxide formed during the hydration of cement has a poor microstructure and thereby causes higher sorptivity (Esam Elawady et al, 2014).

Fig. 2 shows a plot of absorbed water vs the square root of time (in min). The absorption curves are steeper during the early period and gentle at the later period for both CC and BA GPC. The steeper curve signifies that the rate of water absorption was higher earlyon, and the gentle curve indicates that capillary suction was remarkably decreased as time went on. It can also be noted that the rate of water absorption with respect to time was relatively less for BA GPC, while it was sharply increased for CC. Moreover, ASTM C 1585 - 2013 code specifies that the correlation coefficient value $(\mathrm{R})$ between the square root of time and absorption be no less than $\mathrm{R}=0.98$. This condition was satisfied in both control concrete made with cement (CC) and BA GPC.

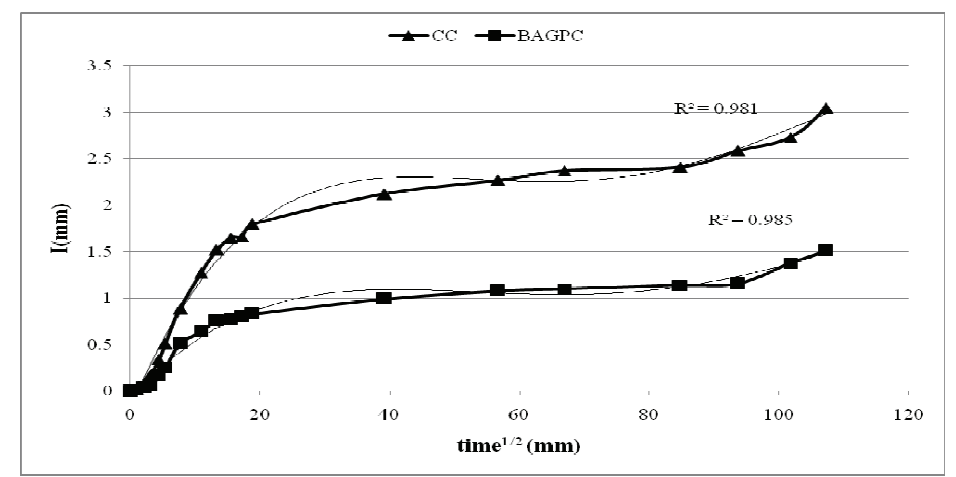

Fig. 2 Sorptivity of CC and BA GPC 
Table 3 Details of sorptivity results

\begin{tabular}{|c|c|c|c|c|c|c|c|}
\hline \multirow[t]{2}{*}{$\begin{array}{c}\text { Time 't' } \\
(\min )\end{array}$} & \multirow[t]{2}{*}{$\begin{array}{l}\text { Square } \\
\text { root of } \\
\text { time }\left(\mathrm{t}^{1 / 2}\right)\end{array}$} & \multicolumn{2}{|c|}{$\Delta$ Mass $(\mathrm{g})$} & \multicolumn{2}{|c|}{$\begin{array}{c}\text { Absorption I } \\
=\Delta \text { Mass/area/ } \\
\text { density of water } \\
(\mathrm{mm})\end{array}$} & \multicolumn{2}{|c|}{$\begin{array}{l}\text { Sorptivity } \\
\mathrm{mm} / \mathrm{t}^{1 / 2}\end{array}$} \\
\hline & & $\mathrm{CC}$ & BAGPC & $\mathrm{CC}$ & BAGPC & $\mathrm{CC}$ & BAGPC \\
\hline 1 & 1.00 & 0.157 & 0.079 & 0.02 & 0.01 & 0.020 & 0.010 \\
\hline 5 & 2.24 & 0.628 & 0.314 & 0.08 & 0.04 & 0.036 & 0.018 \\
\hline 10 & 3.16 & 1.335 & 0.550 & 0.17 & 0.07 & 0.054 & 0.022 \\
\hline 20 & 4.47 & 2.670 & 1.335 & 0.34 & 0.17 & 0.076 & 0.038 \\
\hline 30 & 5.48 & 4.005 & 1.963 & 0.51 & 0.25 & 0.093 & 0.046 \\
\hline 60 & 7.75 & 6.989 & 4.005 & 0.89 & 0.51 & 0.115 & 0.066 \\
\hline 120 & 10.95 & 9.973 & 5.026 & 1.27 & 0.64 & 0.116 & 0.058 \\
\hline 180 & 13.42 & 11.937 & 5.968 & 1.52 & 0.76 & 0.113 & 0.057 \\
\hline 240 & 15.49 & 12.957 & 6.125 & 1.65 & 0.78 & 0.107 & 0.050 \\
\hline 300 & 17.32 & 13.036 & 6.282 & 1.66 & 0.80 & 0.096 & 0.046 \\
\hline 360 & 18.97 & 14.135 & 6.518 & 1.80 & 0.83 & 0.095 & 0.044 \\
\hline 1537 & 39.20 & 14.921 & 7.774 & 2.12 & 0.99 & 0.054 & 0.025 \\
\hline 3220 & 56.75 & 17.826 & 8.481 & 2.27 & 1.08 & 0.040 & 0.019 \\
\hline 4475 & 66.90 & 18.612 & 8.638 & 2.37 & 1.10 & 0.035 & 0.016 \\
\hline 7200 & 84.85 & 18.926 & 8.952 & 2.41 & 1.14 & 0.028 & 0.013 \\
\hline 8793 & 93.77 & 20.339 & 9.109 & 2.59 & 1.16 & 0.028 & 0.012 \\
\hline 10370 & 101.83 & 21.439 & 10.837 & 2.73 & 1.38 & 0.027 & 0.014 \\
\hline 11520 & 107.33 & 23.952 & 11.858 & 3.05 & 1.51 & 0.028 & 0.014 \\
\hline
\end{tabular}

\subsection{WATER ABSORPTION TEST}

Table 4 summarizes the water absorption of $\mathrm{CC}$ and BAGPC. The water absorption of $\mathrm{CC}$ and $\mathrm{BA}$ GPC were found as $3.23 \%$ and $2.06 \%$, respectively, for a 7 -day-cured specimen. The 28 -day-cured specimen reported $1.89 \%$ and $0.95 \%$ water absorption for CC and BA GPC. As expected, BAGPC presented a lower percentage of water absorption than CC. It stands to reason that the higher compressive stregth of BA GPC is responsible for low water absorption due to the enhanced geopolymeric reactions. Moreover, the pore refinement of the BA GP matrix becomes denser due to the fine particles of bottom ash, thereby reducing water absorption. This outcome is in aggrement 
with a previous study carried out by Tianyu Xie and Togay Ozbakkaloglu (2015) on geopolymer concrete made with a bottom ash/fly ash blend. Monita Olivia and Nikraz (2011a) found that the water absorption of low calcium fly ash geopolymer concrete was less than $5 \%$. However, in the present study, water absorption was much lower, indicating a higher degree of geopolymerisation.

Table 4 Results of water absorption

\begin{tabular}{|c|c|c|c|}
\hline Mix ID & $\begin{array}{c}\text { Dry weight } \\
(\mathrm{kg})\end{array}$ & $\begin{array}{c}\text { Wet weight } \\
(\mathrm{kg})\end{array}$ & $\begin{array}{c}\text { \% of water } \\
\text { absorption }\end{array}$ \\
\hline \multicolumn{4}{|c|}{7 days } \\
\hline CC & 2.445 & 2.524 & 3.23 \\
\hline BA GPC & 2.476 & 2.527 & 2.06 \\
\hline \multicolumn{4}{|c|}{28 days } \\
\hline CC & 2.492 & 2.539 & 1.89 \\
\hline BA GPC & 2.518 & 2.542 & 0.95 \\
\hline
\end{tabular}

\section{CONCLUSION}

Focusing the study on some durability properties such as accelerated corrosion, sorptivity, and water absorption of BA GPC, the following conclusions are drawn:

i) Due to enriched geopolymeric reactions, BA GPC showed a $25 \%$ delay in the appearance of the first crack due to accelerated corrosion when compared to conventional concrete. BA GPC imparted excellent resistance against corrosion.

ii) It is visible in the sorptivity test that the initial and final rate of water absorption of BA GPC was nearly two times less than that of equivalent grade control concrete made with cement. BA GPC demonstrated lower absorption of water due to the capillary action of water.

iii) BA GPC presented remarkably lower water absorption than equivalent grade control concrete.

iv) The rapid consumption of silica and alumina of bottom ash within the alkaline activators proves BA GPC as a highly durable compound. 


\section{REFERENCES}

1. Aggarwal.P, Aggarwal.Y, Gupta.S.M, "Effect of bottom ash as replacement of fine aggregates in concrete" Asian journal of civil engineering (building and housing) vol.8, no.1, pp 49-62, 2007.

2. Apha Sathonsaowaphak A, Chindaprasirt P, Pimraksa K, "Workability and strength of lignite bottom ash geopolymer mortar" Journal of Hazardous Materials, vol.168, no.1, pp.44-50, 2009.

3. ASTM C 1585-13 "Standard test method for measurement of rate of absorption of water by hydraulic cement concrete", West Conshohocken, PA.

4. ASTM C 642 - 13 "Standard Test Method for Density, Absorption, and Voids in Hardened Concrete", West Conshohocken, PA.

5. Bastidas.D.M, Fernandez-Jimenez.A, Palomo.A, Gonza-lez.J.A. "A study on the passive state stability of steel embedded in activated fly ash mortars", Corrosion Science, vol.50, no.4, pp.1058-1065, 2008.

6. Chindaprasirt P, Jaturapitakkul C, Chalee W, Rattanasak U "Comparative study on the characteristics of fly ash and bottom ash geopolymers" Waste Management, vol.29, no. 2, pp.539-543, 2009.

7. Chaicharn chotetanorm, Prinya Chindaprasirt, Vanchi sata, Sumrerng Rukzon, Apha sathonsaowaphak "High calcium bottom ash Geopolymer: Sorptivity, pore size, and resistance to sodium sulphate stack", Journal of Materials in civil Engineering, vol.25, pp. 105-111, 2013.

8. Davidovits.J, “Geopolymer - Inorganic polymeric new materials” Journal of thermal analysis, vol. 37, no. 8, pp.1633-1656, 1991.

9. Diana Bajarea, Girts Bumanisb, Liga Upeniecec, "Coal Combustion Bottom Ash as Microfiller with Pozzolanic Properties for Traditional Concrete", Procedia Engineering, vol. 57, pp.149 - 158, 2013.

10. Duxon.P, Provis.J, Grant.L, Mallicoat.S, Kriven.K.M, Van Deventer J.S.J, "Understanding the relationship between geopolymer composition, microstructure and mechanical properties" Colloids and Surfaces A: Physicochemical and Engineering Aspects, vol. 269, no. 1-3, pp.47-58, 2005.

11. Esam Elawady, Amr A. El Hefnawy, Rania A. F. Ibrahim, 'Comparative Study on Strength, Permeability and Sorptivity of Concrete and their relation with Concrete Durability', International Journal of Engineering and Innovative Technology, vol. 4, no. 4, pp.132-139, 2014.

12. Emad Benhelal, Alireza Rafiei, Ezzatollah Shamsaei "Green cement production: potentials and Achievements" International journal of chemical Engineering and application vol.3, no.6, pp. 407-409, 2012.

13. Fernandez-Jimenez A, Palomo.A, "Characterization of fly ashes. Potencial reactivity as alkaline cements" Fuel vol.82, no.18, pp.2259-2265, 2003 .

14. Fernandez-Jimenez A, Palomo.A, Sobrados.I, Sanz.J, “ The role played by reactive alumina content in the alkaline activation of fly ashes" Microporous and Mesoporous Materials, vol. 91, no.1-3, pp.111-119, 2006.

15. Florida Method of Test (FM 5-522-2000) of An Accelerated Laboratory Method for corrosion testing of reinforced concrete specimens using impressed current

16. Ghafoori N, Bucholic.J, "Properties of high-calcium dry bottom ash concrete" ACI Materials Journal, vol.94, pp.90-101, 1997.

17. Hardjito, D. Rangan B.V. "Development and Properties of Low-Calcium Fly Ash-Based Geopolymer Concrete" Curtin University of Technology, Perth, Australia, 2005.

18. Hall.C, "Water movement in porous building materials - I. Unsaturated flow theory and its applications" Building and Environment, vol.12, no.2, pp.117-125, 1997.

19. Hall .C, "Water Sorptivity of Mortars and Concretes: a review", Magazine of Concrete Research, vol. 41, no. 147, pp. 51-61, 1989.

20. Ho.D. W. S, Chirgwin.G. J, "A performance specification for durable concrete" Construction and Building Materials, vol.10, no.5, pp.375-379, 1996.

21. Ilker Bekir Topcu, Mehmet Ugur Toprak, "Properties of geopolymer from circulating fluidized bed combustion coal bottom ash" Material. Science and Engineering: A, vol. 528, no. 3, pp. 1472-1477, 2011.

22. IS 10262 (2009), Recommended Guidelines for Concrete Mix Design, Bureau of Indian Standards, New Delhi, India.

23. IS: 516-1959 (Reaffirmed 2004), Indian Standard methods of Tests for strength of concrete, Bureau of Indian Standards, New Delhi.

24. IS : 4031 ( Part 11 ) - 1988, Methods of physical tests for Hydraulic cement, Part 11 determination of density, Bureau of Indian Standards, New Delhi, India.

25. IS 383 (1987), Specification of coarse and fine aggregate from natural sources for concrete, Bureau of Indian Standards, New Delhi, India.

26. IS 2386 (part 3) (1963), Methods for testing for aggregates for concrete, specific gravity, density, voids, absorption and bulking, Bureau of Indian Standards, New Delhi, India. 
27. IS 12269: 2013, Ordinary Portland Cement, 53 Grade — Specification, Bureau of Indian Standards, New Delhi, India.

28. Kim H K, Lee H K, "Use of power plant bottom ash as fine and coarse aggregate in high-strength concrete", Construction and Building Materials, vol. 25, pp.1115-22, 2011.

29. Logesh Kumar. M, Revathi. V, "Metakaolin bottom ash blend geopolymer mortar- A Feasible Study" Construction and Building Materials, vol. 114, pp. 1-5, 2016.

30. Malhotra.V.M. "Introduction: sustainable development and concrete technology", ACI Concrete. International, vol.24, no.7, pp. 22, 2002.

31. Malkit Singh, Rafat Siddique, "Strength properties and micro-structural properties of concrete containing coal bottom ash as partial replacement of fine aggregate", Construction and Building Materials vol.50, pp.246-256, 2014.

32. McPolin.D.O, "New test method to obtain $\mathrm{pH}$ profiles due to carbonation of concretes containing supplementary cementitious materials" Journal of Materials in Civil Engineering, vol.19, no.11, pp. 936-946, 2007.

33. Mohammed Ba-Shammakh, Hernane Caruso, Ali Elkamel, Eric Croiset, Peter L. Douglas, "Analysis and Optimization of Carbon Dioxide Emission Mitigation Options in the Cement Industry", American Journal of Environmental Sciences vol. 4, no.5, pp.482-490, 2008.

34. Monita Olivia,Hamid R Nikraz, "Durability of fly ash Geopolymer concrete in a Sea Water Environment", Proceedings of the concrete conference, Perth,WA, 2011.

35. Monita Olivia, Hamid Nikraz "Properties of fly ash geopolymer concrete designed by Taguchi method" Materials and Design vol.36, pp. 191-198, 2012.

36. Milagre Martins.I.M, Gonçalves.A, Marques.J.C, "Durability and Strength Properties of Concrete Containing Coal Bottom Ash", In: Brameshuber, W, (ed.) Proceedings pro077 : International RILEM Conference on Material Science - AdIPoC - Additions Improving Properties of Concrete - Theme 3.6-10 September 2010, Aaschen. RILEM Publications SARL, 275 - 283 (9) 2010.

37. Rajamane.N.P, Jeyalakshmi.R, "Quantity of sodium hydroxide solids and water to prepare sodium hydroxide solution of given molarity for Geopolymer concrete mixes" ICI journal, pp.33-36, 2015.

38. Rangan.B. V. "Fly ash-based geopolymer Concrete", Research Report GC 4, Faculty of Engineering, Curtin University of Technology, Perth, Australia, 2008.

39. Rangan.B. V, Wallah, S. E. "Low-calcium fly ash-based geopolymer concrete: long-term properties", Research Report GC 2 Faculty of Engineering Curtin University of Technology Perth, Australia, 2006.

40. Reddy.D.V, Edouard.J.B, Sobhan.K, Rajpathak.S.S. "Durability of Reinforced Fly Ash-Based Geopolymer concrete in the Marine Environment", 36th Conference on our world in concrete \& structures, Singapore, 2011.

41. Revathi.V, Saravanakumar.R, Thaarrini.J, "Effect of molar ratio of $\mathrm{SiO}_{2} / \mathrm{Na}_{2} \mathrm{O}, \mathrm{Na}_{2} \mathrm{SiO}_{3} / \mathrm{NaOH}$ ratio and Curing Mode on Compressive Strength of Ground Bottom Ash Geopolymer Mortar", International Journal of Earth Science and Engineering, vol. 07, no.4, pp. 1511-1516, 2014.

42. Si-Hwan Kim, Gum-Sung Ryu, Kyung-Taek Koh, Jang-Hwa Lee "Flowability and Strength Development Characteristics of Bottom Ash based Geopolymer" World Academy of Science, Engineering and Technology, vol.70, pp. 53-59, 2012.

43. Tianyu Xie, Togay Ozbakkaloglu, "Influence of coal ash properties on compressive behaviour of FA- and BAbased GPC", Magazine of Concrete Research, pp. 1-14, 2015.

44. Tianyu Xie, Togay Ozbakkaloglu "Behavior of low-calcium fly and bottom ash-based geopolymer concrete cured at ambient temperature" Ceramics International, vol.41, pp. 5945-5958, $2015 \mathrm{a}$.

45. Vanchai Sata, Apha Sathona Saowaphak,Prinya Chindaprasirt, "Resistance of Lignite Bottom Ash Geopolymer Mortar to Sulfate and Sulfuric Acid Attack" Cement and Concrete Composites, vol.34, pp. 700-708, 2012.

46. Yodmunee.S, Yodsujai.W, "Study on corrosion of steel bar in fly ash based geopolymer concrete", Proceedings, International Conference on Pozzolan, Concrete and Geopolymer, Khon Kaen, Thailand, pp.24-25 May 2006. 


\section{LIST OF FIGURES AND TABLES:}

Tab. 1. Mix proportions of BAGPC and CC

Tabela 1. Proporcje mieszanki betonu geopolimerowego na bazie popiołu dennego i betonu cementowego

Tab. 2.Test Results for Compressive Strength

Tabela 2. Wyniki badań wytrzymałości na ściskanie

Tab.3. Details of Sorptivity Results

Tabela 3. Szczegóły wyników sorpcyjności

Tab. 4. Results of water absorption

Tabela 4. Wyniki absorpcji wody

Fig.1. The Relationship Between Current Passed and Duration of Time

Rys. 1. Związek pomiędzy czasem obecnym, byłym a trwającym

Fig. 2. Sorptivity of CC and BA GPC Rys. 2. Sorpcyjność betonu cementowego i betonu geopolimerowego na bazie popiołu dennego

Rys. 2. Sorpcyjność betonu cementowego i betonu geopolimerowego na bazie popiołu dennego 


\section{NIEKTÓRE ASPEKTY TRWALOŚCI BETONU GEOPOLIMEROWEGO NA BAZIE POPIOLU DENNEGO UTWARDZANEGO W TEMPERATURZE OTOCZENIA}

Słowa kluczowe: popiół denny, aktywatory alkaliczne, utwardzanie otoczenia, przyspieszona korozja, sorpcja, chłonność wody

\section{Streszczenie:}

W przypadku proponowania oraz dostosowywania popiołu dennego jako materiału źródłowego w betonie geopolimerowym, ważne jest, aby oprócz jego właściwości wytrzymałościowych, zapewnić jego wydajność w odniesieniu do aspektów trwałości. Jak wynika z poprzednich badań, należy rozumieć, iż istnieje luka w pewnym wykorzystywaniu betonu geopolimerowego na bazie popiołu dennego. W związku z tym, w niniejszej pracy zbadano wydajność betonu geopolimerowego na bazie popiołu dennego pod kątem przyspieszonej korozji, sorpcyjności oraz absorpcji wody. W odniesieniu do proporcji mieszanki, klasa betonu została zaprojektowana dla $40 \mathrm{MPa}$. Do wywołania reakcji geopolimerycznych zastosowano aktywatory chemiczne na bazie sodu. Ilość roztworu chemicznego została przyjęta jako 0,5-krotność masy materiału źródłowego. Zachowanie betonu geopolimerowego na bazie popiołu dennego porównano z typowym betonem cementowym. Badania wytrzymałościowe wskazują, że beton geopolimerowy na bazie popiołu dennego wykazał większą wytrzymałość niż beton cementowy. Podczas gdy kilku badaczy zaleca utwardzanie termiczne w celu aktywacji betonu geopolimerowego, na tym etapie można stwierdzić, że beton geopolimerowy na bazie popiołu dennego osiągnął wytrzymałość przy utwardzaniu w temperaturze otoczenia. Ze względu na przyspieszoną korozję, czas rozpoczęcia korozji betonu geopolimerowego na bazie popiołu dennego został wydłużony 1,76 razy w porównaniu $z$ betonem cementowym. Beton geopolimerowy na bazie popiołu dennego tym samym zwiększył bardziej katodową reakcję oraz zmniejszył aktywność korozyjną ze względu na wzmocniony proces reakcji polimerowej. Ze względu na efekt wypełniacza mikrocząsteczek popiołu dennego, a także reakcję geopolimeryzacji pomiędzy popiołem dennym a aktywatorami alkalicznymi, betonowi geopolimerowemu na bazie popiołu dennego przypisano wyraźnie niższą sorpcyjność. Natomiast wyższa wytrzymałość na ściskanie betonu geopolimerowego na bazie popiołu dennego wykazała niższą absorpcję wody. Można zatem stwierdzić, że beton geopolimerowy na bazie popiołu dennego utwardzony w temperaturze otoczenia jest uznawany za wysoce wytrzymały materiał kompozytowy. 